\title{
Tiおよび $\mathrm{Ti}$ 合金の空気中酸化について
}

\section{室 井 新一郎* 染 野檀}

Shin-ichiro Muroi and Mayumi Someno: The Oxidation of Titanium and its Alloys in Air. Investigations were made on the oxidation of titanium and binary titanium alloys containing $3 \% \mathrm{~A} 1,3 \% \mathrm{Mn}, 7 \% \mathrm{Mn}, 3 \% \mathrm{Fe}$ and $7 \% \mathrm{Fe}$, respectively. Oxidation/time curves were measured at $900^{\circ} \sim 1000^{\circ} \mathrm{C}$ in air, and oxidized specimens were examined by $\mathrm{X}$-ray diffraction, electron beam X-ray microanalysis, microhardness and metallographic techniques. Rutile was the only oxide detected on titanium and its alloys under the experimental conditions, but a trace of manganese titanate was observed in the scale of a Ti-7\% $\mathrm{Mn}$ alloy. The $\alpha$-phase was found on the rim of underlying metals by dissolving oxygen, but its morphology in titanium alloys oxidized above the transformation temperature differs from that of unalloyed titanium. The hardness gradient, that is, the oxygen gradient was remarkable in the $\alpha$-band, but not detected in the elongated $\alpha$-grains. In oxidized samples of $\mathrm{Ti}-\mathrm{Mn}$ and $\mathrm{Ti}-\mathrm{Fe}$ alloys, marked manganese and iron enrichments were observed in the $\beta$-phase next to the $\alpha / \beta$ interface, but such a enrichment of aluminum in $\mathrm{Ti}-3 \% \mathrm{Al}$ alloy was not observed.

(Received, November 30, 1964)

\section{I. 粕言}

純 Ti の高温酸化については多くの研究があり(1)〜(11), 著 者の一人も微量熱天科を用いて初期酸化について報告した (9).これらの結果をみると, $800^{\circ} \mathrm{C}$ 以下の温度ではかなり よく一致しているが，これより高温では一致が悪い，これ は試料中の不純物や前処理の相違などに基くと考光られて いる.Ti 合金の酸化過程に括ける合金成分の挙動を調べる ことは, Ti の高温酸化の解明の一助となると考えられる が，こ礼関する報告は比較的少ない(10) (13). 純 $\mathrm{Ti}$ の変 態点は約 $880^{\circ} \mathrm{C}$ であるが，合金元素には变態点を上昇させ るもの( $\mathrm{Al}, \mathrm{Zr}, \mathrm{C}, \mathrm{O}, \mathrm{N}$ な゙゙)と降下させるもの( Fe, Cr， $\mathrm{Cu}, \mathrm{Ni}, \mathrm{Mn}, \mathrm{Co}, \mathrm{Mo}$ など)とある。従来の研究に上れば, $\beta$ 相中の酸素の拡散速度は $\alpha$ 相の場合より非常に速い(14) が，酸素溶解度は $\alpha$ 相より非常に少ないことが知られてい

* 山梨大学学芸学部 (The Faculty of Liberal Arts and Education, Yamanashi University, Kofu)

** 東京工業大学金属工学科 (Department of Metallurgy, Tokyo Institute of Technology, Tokyo)

(1) E.A.Gulbransen and K.F.Andrew: Trans. AIME, 185 (1949),741.

(2) P.H.Morton and W.M.Baldwin: Trans, ASM, 44 (1952), 1004 .

(3) A.E. Jenkins: J.Inst. Metals, 82 (1953 54),213.

(4) W.Kinna and W.Knorr : Z.Metallk., 47(1956), 594.

(5) J.Stringer: Acta Met., 8(1960),758.

(6) P. Kofstad, K. Hauffe and H. Kjöllesdal : Acta Chem.Scand., 12(1958), 239 .

(7) T.Hurlen: J. Inst. Metals, $89(1960 \sim 61), 128$.

(8) D.I.Layner and A.S.Bay: Phys. Met. a Metallog., 14 (1962), 107.

(9) 染野: 真空, 3(1960) ,No.2,11.

(10) 小叫, 渡辺, 竹内, 川西：本誌, 21 (1957)，410.

(11) 足立, 过本：本誌, 22(1958),379.

(12) A.E.Jenkins: J.Inst. Metals, 84 (1955 56), 1 .

(13) J.Stringer: J. Inst. Metals., 90 (1961 62), 298

(14) W.P. Roe, H.R. Palmer and W.R. Opie: Trans. ASM, 52(1960), 191.
て，これらはTi合金の酸化速度に影響することが考穴ら れる。

本報告は合金元素が酸化挙動に扣よぼす影響を調べるた め, 純 $\mathrm{Ti}$ 拉上び $\mathrm{A} 1, \mathrm{Fe}, \mathrm{Mn}$ 拿も 2 元 $\mathrm{Ti}$ 合金につい $\tau, 900^{\circ} \sim 1000^{\circ} \mathrm{C}$ の空気中で酸化し, 重量变化の測定, 酸化被膜・下地金属の組織検查执よびX線マイクロアナラ イザによる䟴度分有の測定などを行なつた結果に関するも のである。

\section{II. 実 験 方 法}

1. 試料

原料として使用したチタンスポンジは Table 1 に示す 組成のクロールチタンである。Ti 合金としてはTable 2 に示す組成のものをいずれも真空アーク溶解した，溶解量

Table 1 Chemical composition of Titanium sponge used. (\%)

\begin{tabular}{c|c|c|c|c|c}
\hline $\mathrm{Fe}$ & $\mathrm{Cl}$ & $\mathrm{N}$ & $\mathrm{Al}$ & $\mathrm{Cr}$ & $\mathrm{Mg}$ \\
\hline 0.016 & 0.081 & 0.005 & $\mathrm{tr}$ & 0.0003 & 0.035 \\
\hline $\mathrm{Mn}$ & $\mathrm{Si}$ & $\mathrm{V}$ & $\mathrm{C}$ & $\mathrm{O}$ & $\mathrm{H}$ \\
\hline 0.001 & 0.007 & $\mathrm{tr}$ & 0.019 & 0.025 & 0.0023 \\
\hline
\end{tabular}

Table 2 Chemical analysis of ailoying elements.

\begin{tabular}{c|c}
\hline Alloy & Chemical composition \\
\hline Pure Ti & $-\overline{\mathrm{T}}$ \\
$\mathrm{Ti}-3 \mathrm{Al}$ & $3.06 \% \mathrm{Al}$ \\
$\mathrm{Ti}-3 \mathrm{Mn}$ & $3.25 \% \mathrm{Mn}$ \\
$\mathrm{Ti}-7 \mathrm{Mn}$ & $5.95 \% \mathrm{Mn}$ \\
$\mathrm{Ti}-3 \mathrm{Fe}$ & $2.72 \% \mathrm{Fe}$ \\
$\mathrm{Ti}-7 \mathrm{Fe}$ & $7.08 \% \mathrm{Fe}$ \\
\hline
\end{tabular}

は約 $4 \mathrm{~kg} て ゙$ 再溶解後熱間圧延により板とし，試験片をも り出して寒験に供した。試験片の寸法は，酸化增量の測定 
Kは $20 \times 10 \times 5 \mathrm{~mm}$, 影微鋎検査には $8 \times 5 \times 4 \mathrm{~mm}$ とし， 表面をエミリー紙05まで研摩し，ベンゼンで脱脂洗浄し たのら使用した。

\section{2. 試跲方法}

酸化增量は熱天科を用い1 気压の空気中で $900^{\circ}, 950^{\circ}$ ， $1000^{\circ} \mathrm{C}$ の各温度につき同一試料で $10 \mathrm{~min}$ 毎に $6 \mathrm{hr}$ 測定 した．検鏡試料は上記温度に 1 6 hr 間保持後空冷したも のを樹脂に埋め試料表面を削りとり試料の中央部断面を 调へた。，検鏡試料のうちいくつかのものについて，X線マ イクロアナライザにより組成元素の分布を調べた。 この場 合試料の研摩剂として, Ti-3 Al 合金については酸化ク口 ム，他の陚料についてはフルミナを使用した。試料断面の 硬度分布を微小硬度計により測定し，また酸化被膜の同定 をX線回折により行なつた。

\section{III. 実験結果および考察}

\section{1. 酸化增}

純 Tiについて一般に酸化増量 $W$ と時間 $t$ との関係は $W^{n}=k t \quad k:$ 反応速度定数

で表わされる，Fig.1は紏 Ti の酸化増量と時間との関係

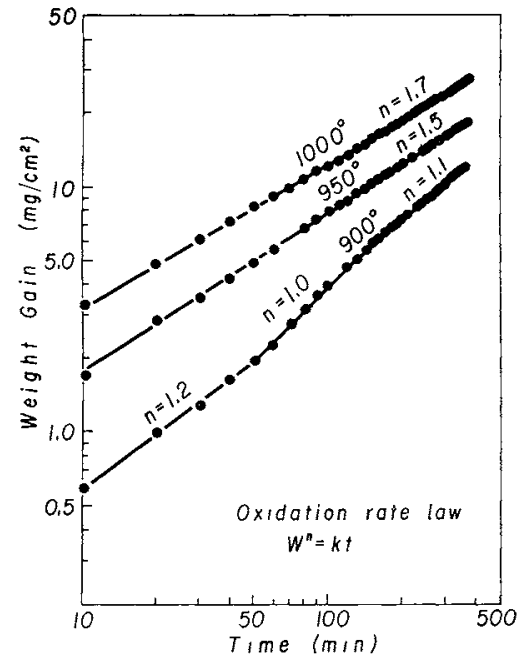

Fig. 1 The oxidation of pure $\mathrm{Ti}$ at $900^{\circ}$ to $1000^{\circ} \mathrm{C}$ in air.

を示したすので， $\log W-\log t$ の直線の勾配から指数 $n$ を

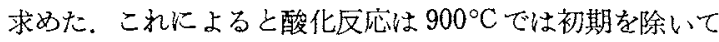
直線則にしたがうが，950。，1000 Cでは勾配は直線則と放 物線則の中間にあることになる。

純 Ti の酸化反応関する従来の報告を又るに，一般に 高温では放物線則にしたがうが，先の後反度速度が前より 大さな放物線則にしたが 5 場合や，最初の放物線則ののら 直線則にしたが5場合などがある(2) (6)，また出所の異な る試料では酸化の際異なる挙動を示し，必ずしも放物線則 あるいは直線則にしたがわず，両者の中間の関係を示す場 合 (2)(4)(6) 報告されている。これらは高盜での酸化反応が
複雑な因子を含み，酸化試料の酸化被膜・下地金属の組織 などをさらに㛟討する必要のあることを示するのとい文

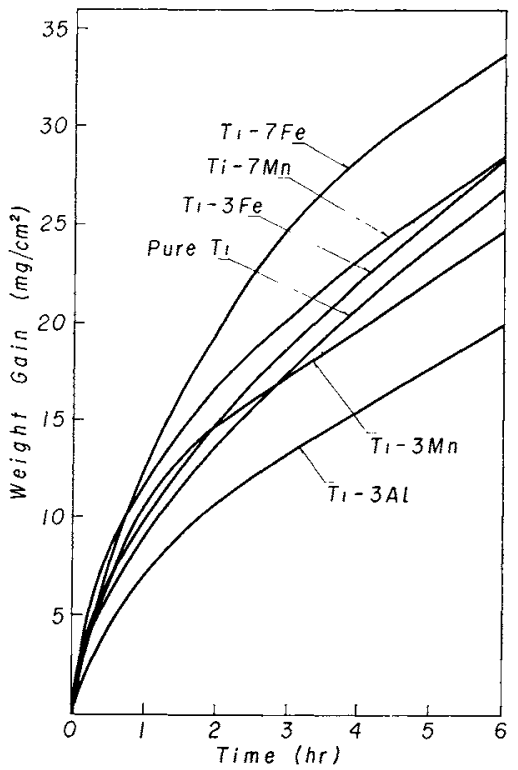

Fig.2 Some typical oxidation curves for $\mathrm{Ti}$ and its alloys at $1000^{\circ} \mathrm{C}$ in air.

5.

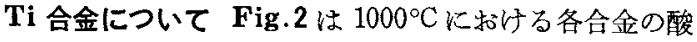
化增量と時間の関係を示したものである，Ti 合金の酸化 堌量を純 Ti のとれと比較すると, $900^{\circ} \sim 1000^{\circ} \mathrm{C}$ では Ti-3 Mn, Ti-7 Mn, Ti-3 Fe 合金ではほとんど差はないが, Ti$7 \mathrm{Fe}$ 合金では幾分多く，Ti-3 Al 合金では常に少ないよう である.A1 4 6\%の添加はTi-A1 合金の高温での 耐酸化 性を良好にする(15)が， Ti-6.6\% Fe 合金の酸化增量性純 $\mathrm{Ti}$ より大さい(12)とする報告と一致している。 Ti 合金の酸化 増量と時間との関係から指数 $n$ 在求めた結果を Table 3 に示した。 Ti-3 Al 合金ではnの值は初期にはいずれも 1.5 であるが，80〜90 min 後には $900^{\circ} \mathrm{C}$ では1.1に減少 し反

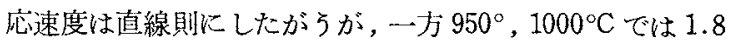
に増加して反応速度は放物線則に近づくよ5である。同様 な傾向は他の Ti 合金についても認められる。

\section{2. 酸化被膜}

酸化被膜の色は合金元素とその含有量, 酸化温度および 時間によつて異なる。たとえば $6 \mathrm{hr}$ 酸化した場合，純 Ti 括よびTi-3 Al, Ti-3 Fe, Ti-7 Fe 合金では $900^{\circ} \mathrm{C} て ゙$ 灰 白色， $950^{\circ} \mathrm{C}$ で白色， $1000^{\circ} \mathrm{C}$ て淡黄色であるが，このうち $\mathrm{Ti}-\mathrm{Fe}$ 合金では試料の稯線の部分が赤褐色を呈した。この 場合温度が高いほど，また鉄含有量の多い合金がこの傾问

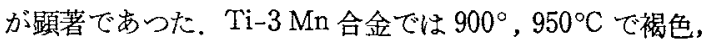
$1000^{\circ} \mathrm{C}$ で两色, Ti-7 Mn 合金では $900^{\circ}, 950^{\circ} \mathrm{C}$ で黑裮 色， $1000^{\circ} \mathrm{C}$ で灰黒色であつた，酸化被膜は板状に 跑離し やすいが，重面はいずれも白色であつた，酸化被膜にはこ

(15) S.G.Gvozder: Chem.Abstract, 54(1960), 10778 i. 
のほかに䐣離せずに下地金属に付着している内側の部分が あり，これは一般にもろく多孔質であるが，粉末状のもの

Table 3 The exponent $n$ in the equation of oxidation rate law for Ti-alloys.

\begin{tabular}{|c|c|c|c|c|c|c|}
\hline Alloy & $\begin{array}{c}\text { Temp. } \\
\left({ }^{\circ} \mathrm{C}\right)\end{array}$ & $n$ & $\begin{array}{l}\text { Change of } n \\
\text { at time } \\
\text { (min) }\end{array}$ & $\begin{array}{c}\mathrm{New} \\
n\end{array}$ & $\begin{array}{l}\text { Further } \\
\text { change } \\
\text { of } n \text { at } \\
\text { time } \\
\text { (min) }\end{array}$ & New $n$ \\
\hline $\begin{array}{l}\mathrm{Ti}- \\
3 \mathrm{Al}\end{array}$ & $\begin{array}{r}900 \\
950 \\
1000\end{array}$ & $\begin{array}{l}1.5 \\
1.5 \\
1.5\end{array}$ & $\begin{array}{l}80 \\
90 \\
90\end{array}$ & $\begin{array}{l}1.1 \\
1.8 \\
1.8\end{array}$ & - & - \\
\hline $\begin{array}{l}\mathrm{Ti}- \\
3 \mathrm{Mn}\end{array}$ & $\begin{array}{r}900 \\
950 \\
1000\end{array}$ & $\begin{array}{l}1.5 \\
1.5 \\
1.5\end{array}$ & $\begin{array}{l}80 \\
80 \\
80\end{array}$ & $\begin{array}{l}1.4 \\
1.7 \\
2.5\end{array}$ & $\begin{array}{l}- \\
120 \\
240\end{array}$ & $\begin{array}{l}\overline{2.1} \\
1.8\end{array}$ \\
\hline $\begin{array}{l}\mathrm{Ti}- \\
7 \mathrm{Mn}\end{array}$ & $\begin{array}{r}900 \\
950 \\
1000\end{array}$ & $\begin{array}{l}1.5 \\
1.5 \\
1.5\end{array}$ & $\begin{array}{r}180 \\
60 \\
40\end{array}$ & $\begin{array}{l}1.9 \\
1.9 \\
2.0\end{array}$ & - & - \\
\hline $\mathrm{Ti}_{3 \mathrm{Fe}}$ & $\begin{array}{r}900 \\
950 \\
1000\end{array}$ & $\begin{array}{l}1.4 \\
1.5 \\
1.7\end{array}$ & $\begin{array}{l}100 \\
- \\
-\end{array}$ & $\begin{array}{l}1.2 \\
-\end{array}$ & $\begin{array}{l}- \\
-\end{array}$ & - \\
\hline $\mathrm{Ti}^{7} \mathrm{Fe}$ & $\begin{array}{r}900 \\
950 \\
1000\end{array}$ & $\begin{array}{l}1.5 \\
1.2 \\
1.3\end{array}$ & $\begin{array}{r}80 \\
120 \\
90\end{array}$ & $\begin{array}{l}1.0 \\
2.0 \\
2.0\end{array}$ & $\begin{array}{l}\overline{180} \\
180\end{array}$ & $\begin{array}{l}\text { * } \\
\text { *urved } \\
\text { *curved }\end{array}$ \\
\hline
\end{tabular}

* $\log W-\log t$ plot is not linear, but curved.

ああつた。

$950^{\circ} \mathrm{C}, 6 \mathrm{hr}$ での酸化被膜断面の 顕微鏡組織を Photo. 1 (a)〜 (c)に示す. 同図 (a) は純 Ti の場合で外側の酸化被膜 は試料表面に平行な多数の薄い層からなり, 内側の酸化被 膜は暗灰色を呈していた。 $\mathrm{Ti}-3 \mathrm{Fe}, \mathrm{Ti}-7 \mathrm{Fe}$ 合金では外側 酸化被膜は純 $\mathrm{Ti}$ とよく似た層状組織で, 内側の酸化被膜 は白色のものと暗灰色のものとからできていた，Ti-3 Mn 合金では外側酸化被膜は純 Ti と息とんど同じ位の厚さで あるが，内側酸化被膜は幾分厚く(同図 b)，Ti-3 A 1 合金 では外側酸化被膜は純 Tiよりかなり薄いが，内側酸化被 膜は厚くなつていた (同図 c). Stringer (5) は高温では純 Ti の酸化被膜は金属表面に生じた酸化物の薄い層の blistering の繰り返しによつて層状に生じるとしているが，本 実験の結果とも一致している.

Fig.3 は純 $\mathrm{Ti}$ の $1000^{\circ} \mathrm{C}, 6 \mathrm{hr}$ に扣ける酸化被膜の $\mathrm{X}$ 線 回折の結果である. 外側の酸化被膜はルチル型 $\mathrm{TiO}_{2}$ のみ で, 内側の酸化被膜†ではルチルの強度が低く, これとは 異なつた回折線 ( $\downarrow$ 印)が強くあらわれている.

純 $\mathrm{Ti}$ の酸化被膜については, $850^{\circ} \mathrm{C}$ 以上では外側から 内側へ $\mathrm{TiO}_{2}$ (ルチル), $\mathrm{Ti}_{2} \mathrm{O}_{3}, \mathrm{TiO}$ の順に形成されるとす るもの(2)(4) と, $\mathrm{Ti}_{2} \mathrm{O}_{3}, \mathrm{TiO}$ は認められないとするもの (6)(10)(11) とがある. 本実験の結果では外側酸化被膜はルチ ルのみが認められた。内側酸化被膜のよ印で示したものは Andersonet al(16) による $\mathrm{Ti}_{2} \mathrm{O}$ に相当している. Table 4

$\dagger$ 外側酸化被膜を䖨離した試料表面についてX線回折 を行なつた。

(16) S. Anderson et al: Acta. Chem. Scand., 11 (1957), 1641 ; ibid., 11 (1957) ,1653.
にこのものの面間隔を ASTM Card の data(17) と比較して 示した。 この $\mathrm{Ti}_{2} \mathrm{O}$ の組成は $\mathrm{Ti}-\mathrm{O}$ 状態図(18)によると， $\alpha$ -

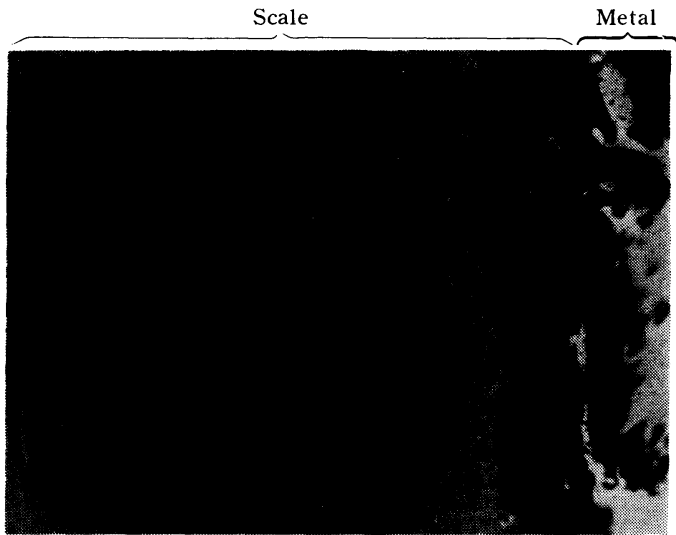

(a) pure $\mathrm{Ti}$

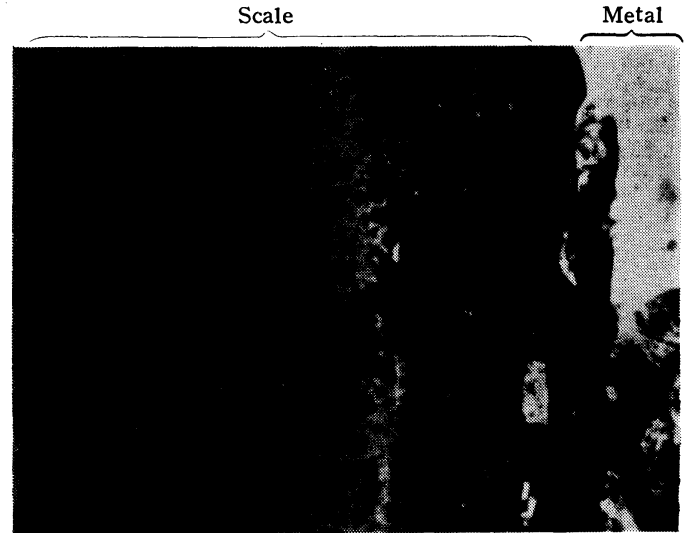

(b) $\mathrm{Ti}-3 \mathrm{Mn}$

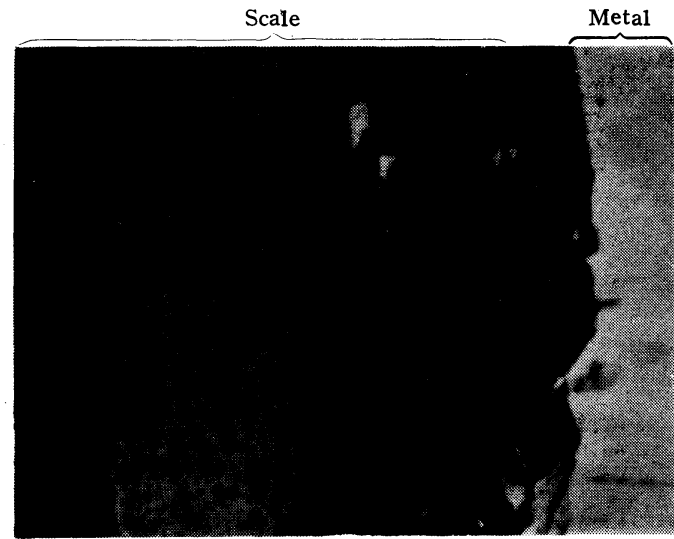

(c) $\mathrm{Ti}-3 \mathrm{Al}$

Photo. 1 Microstructures of scales on $\mathrm{Ti}$ and its alloys oxidized at $950^{\circ} \mathrm{C}$ for 6 hours.

$(\times 400)$

$\mathrm{Ti}$ の酸素固溶限 (34 at\%) に対応している.

$\mathrm{Ti}$ 合金の酸化被膜も X 線回折の 結果いずれも大部分儿 チルであつた， Ti-7 Fe 合金のX線マイクロアナライザの line analysis (Fig.4 b) によると, 酸化被膜のルチル中の Fe 含有量は少ないが, point analysis の強度比からの結果 では Fe 0.127\% であつた。一方同温度における 酸化被膜

(17) ASTM, X-ray Powder Data File No.11 218.

(18) E.S.Bumps, H.D. Kessler and M.Hansen: Trans. ASM,45(1953) ,1008. 
を化学分析した結果Feは $0.55 \%$ であつた。 Jenkins ${ }^{(12)} に$ 上れば Ti-6.6 Fe 合金の $950^{\circ} \mathrm{C}$ に抢ける酸化被膜を化学分

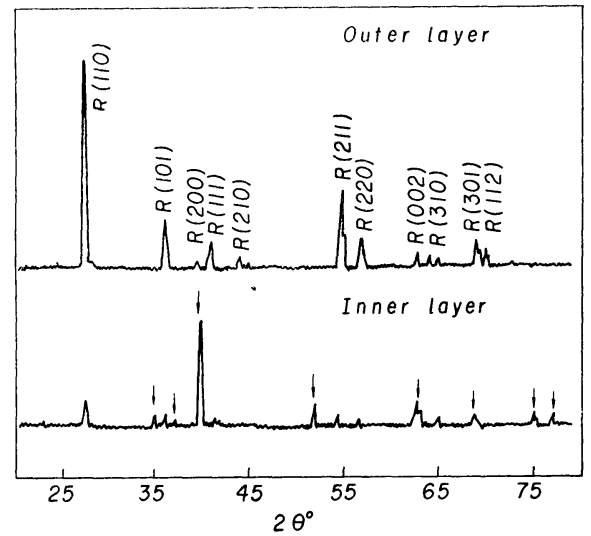

Fig.3 X-ray diffraction patterns obtained from the scales formed on pure $\mathrm{Ti}$ at $1000^{\circ} \mathrm{C}$ for 6 houres $(\mathrm{Cu}-\mathrm{K} \alpha)$.

Table $\perp$ Lattice spacings of $\mathrm{Ti}_{2} \mathrm{O} .(\mathrm{Cu}-\mathrm{K} \alpha)$

\begin{tabular}{|c|c|c|c|c|}
\hline \multirow{2}{*}{$h k l$} & \multicolumn{2}{|c|}{ Observed } & \multicolumn{2}{|c|}{ ASTM No. $11 \sim 218$} \\
\hline & $d(\AA)$ & $I / I_{1}(\%)$ & $d(\AA)$ & $I / I_{1}(\%)$ \\
\hline $\begin{array}{l}100 \\
002 \\
101 \\
102 \\
110 \\
103 \\
200 \\
112\end{array}$ & $\begin{array}{l}2.57 \\
2.41_{7} \\
2.270 \\
1.761 \\
1.483 \\
1.375 \\
1.282 \\
1.263\end{array}$ & $\begin{array}{r}14 \\
3 \\
100 \\
21 \\
23 \\
6 \\
2 \\
6\end{array}$ & $\begin{array}{l}2.56 \\
2.422 \\
2.265 \\
1.761 \\
1.480 \\
1.366 \\
1.281 \\
1.264\end{array}$ & $\begin{array}{r}60 \\
60 \\
100 \\
80 \\
80 \\
60 \\
20 \\
60\end{array}$ \\
\hline
\end{tabular}

析した結果では $\mathrm{Fe}$ 含有量が $2.2 \%$ に减少している。 point analysis の結果が低いのは Ti など共存元素によるX X 線の 吸収, 試料表面が平滑でないための散乱などの影響や, 被 膜中の $\mathrm{Fe}$ 含有量の不均一性に基くものと考兄られる.

Ti-7 Mn 合金の外側酸化被膜はル・チル以外の回折線が認 められ，これらの面間隔と強度をTable 5に示した。 X 線マイクロアナライザの line analysis の結果では外側酸 化被膜に Mn rich の部分が認められ，また化学分析の結

Table 5 Lattice spacings of $\mathrm{MnTiO}_{3}$. $(\mathrm{Cu}-\mathrm{K} \boldsymbol{\alpha})$

\begin{tabular}{c|r|r|r|r}
\hline \multirow{2}{*}{$h k l$} & \multicolumn{2}{|c|}{ Observed } & \multicolumn{2}{c}{ ASTM No.12 435 } \\
\cline { 2 - 5 } \cline { 4 - 5 } & $d(\AA)$ & $I / I_{1}(\%)$ & $d(\AA)$ & $I / I_{1}(\%)$ \\
\hline 104 & 2.771 & 60 & 2.76 & 100 \\
110 & 2.556 & 100 & 2.55 & 70 \\
113 & 2.241 & 30 & 2.25 & 40 \\
024 & 1.880 & 20 & 1.88 & 60 \\
116 & 1.739 & 40 & 1.74 & 70 \\
214 & 1.523 & 20 & 1.52 & 50 \\
300 & 1.479 & 30 & 1.48 & 50 \\
119 & 1.350 & 20 & 1.35 & 10 \\
\hline
\end{tabular}

果 Mn 0.8\%を含むので $\mathrm{Mn}$ 化合物について該当するもの をASTM Cardについて調べた結果， $\mathrm{MnTiO}_{3}(19)$ と比較

(19) ASTM, X-ray Powder Data File No.12-435.
的よく一致することがわかつた。内側の酸化被膜には $\mathrm{Mn}$ の化合物に該当するものは見当らなかつた。

Ti-3 Al 合金について外側の酸化被膜をX線 マイクロア ナライザの line analysis で調べた結果，A1 はほとんど含 有しないが，酸化被膜中に Al rich の部分が認められる場 合もあつた。 Jenkins ${ }^{(12)}$ は表面の酸化被膜を䟝離して化学 分析した結果 $\mathrm{A} 1$ が相当量存在するとし，一方小川ら (10)の 電子回折結果では酸化被膜はルチルであり, $\mathrm{Al}$ の存在は 認められなかつたとしている。本試料をX 線回折したが該 当する $\mathrm{Al}$ 化合物は見当らなからた。

\section{3. 下地金属の組樴}

Photo.2 (a) (f) は $950^{\circ} \mathrm{C}, 6 \mathrm{hr}$ 酸化した試料の下地金 属の顕微鏡組織である.

(a) は純 Ti の場合であるが，下地金属は二相からなり， 周縁は $\alpha$ 相 $(\alpha-T i$ と酸素の固溶体) が帯状に生じ，内部は 処理温度では $\beta$ 相であつた部分で急冷のためWidmanstätten structure を示している. Table 6 は酸化被膜と $\alpha$ 相 の厚さを $950^{\circ} \mathrm{C} て ゙$ 酸化した試料について比較したものであ るが，この温度では酸化被膜は時間に比例して厚さを増 し， $\alpha$ 相も時間とともに厚さが増加している。

(b)の Ti-3 Al 合金では周縁は酸素を固溶した $\alpha$ 相が带 状に生じ, 内部は処理温度では $\alpha+\beta$ 相であつたもので $\alpha$ 相を示している。しかし $1000^{\circ} \mathrm{C}, 6 \mathrm{hr}$ では Photo. 3 のよ 5 に酸素を固溶した $\alpha$ 相は周縁に帯状に生じ，さらに内部 へ柱状に成長している部分も認められる。また内部は処理 温度では $\beta$ 相であつた部分でWidmanstätten structure を 示している.

(c) は Ti-3 Mn，(d) は Ti-7 Mn 合金の場合であるが， $\alpha$ 相 $(\alpha-\mathrm{Ti}$ と酸素の固溶体) は柱状に成長しているものが多 く, 純 Ti, Ti-3 Al 合金の場合とは著しく異なつている.

(e)の Ti-3 Fe 合金では酸素を固溶 した $\alpha$ 相は带状に生 じ，これからさらに柱状に成長している，処理温度で $\beta$ 相 であつた部分のうち $\alpha$ 相に接近した部分は腐食されにく いが, 内部は martensiticな組織を示している.(f) の Ti$7 \mathrm{Fe}$ 合金では酸素を固溶した $\alpha$ 相がやはり柱状に成長して いるが，Ti-3 Fe 合金の場合よりも $\alpha$ 柱の数が多く， また 内部は腐食されにくいが， $\alpha$ 柱の層と接して腐食されやす い部分があり，特有な組織を示している。

Stringer ${ }^{(13)}$ は Ti-Fe 合金について変態点以上で酸化した 場合下地金属周縁に生じた $\alpha$ 相は異状成長することを述べ ているが，本実験結果によると Ti-Fe 合金のほかに Ti$\mathrm{Mn}$ 合金, Ti-Al 合金についても $\beta$ 相領域では $\alpha$ 相が異常 成長することが認められた，柱状 $\alpha$ 相は方向性があり, 結 晶粒内を横切つて成長するが, 結晶粒界でとまり, 隣の結 晶粒へは入らずにさらに粒界に沿つて成長するようであ る。また酸化温度が高いほど $\alpha$ 相の数が少なくなるが大き く成長することが認められた。

$\alpha$ 相の 異状成長の 原因は複雑であるが，その一つとし $\tau, \beta$ 相中の酸素拡散速度が $\alpha$ 相の場合にくらべて非常に 


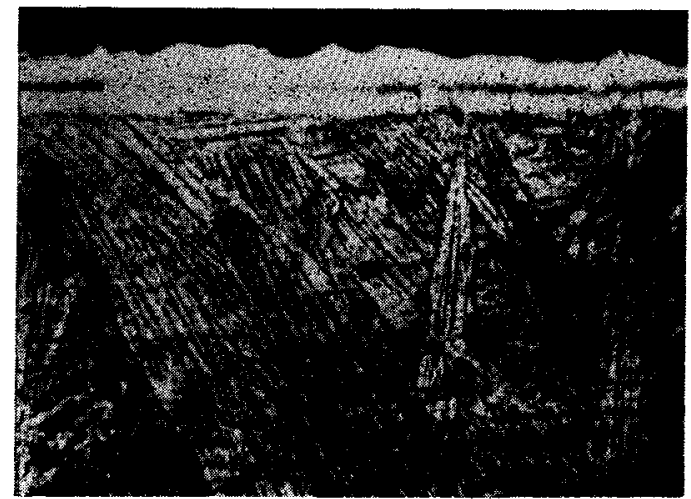

(a) pure $\mathrm{Ti}$

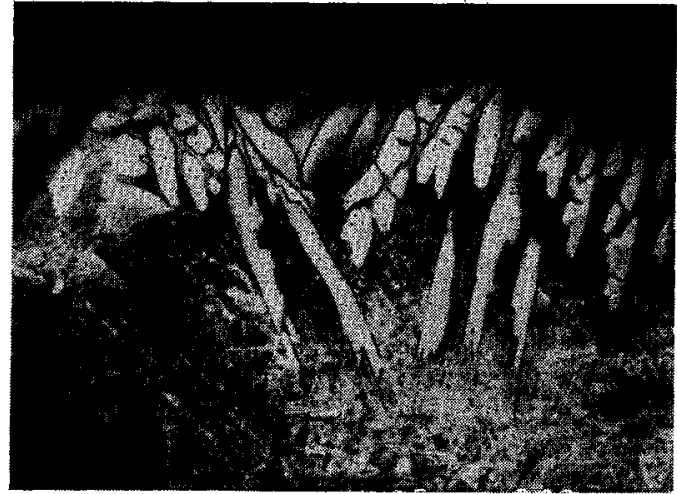

(c) $\mathrm{Ti}-3 \mathrm{Mn}$

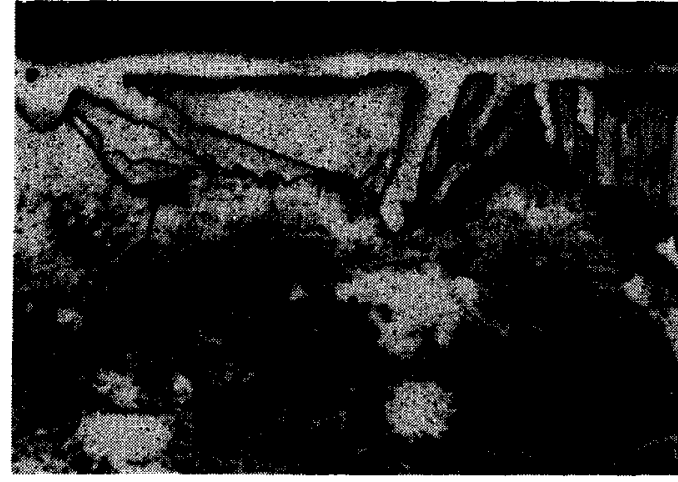

(e) $\mathrm{Ti}-3 \mathrm{Fe}$

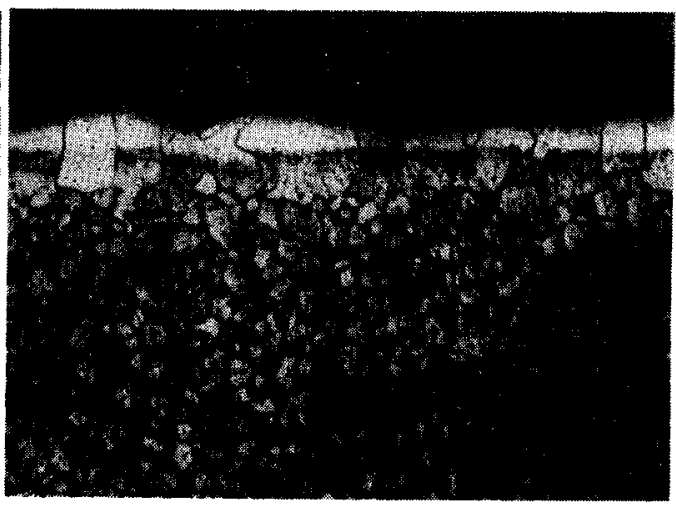

(b) $\mathrm{Ti}-3 \mathrm{Al}$

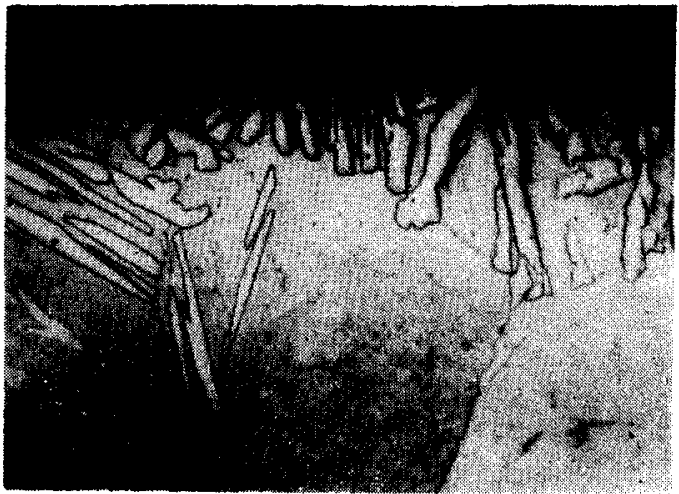

(d) $\mathrm{Ti}-7 \mathrm{Mn}$

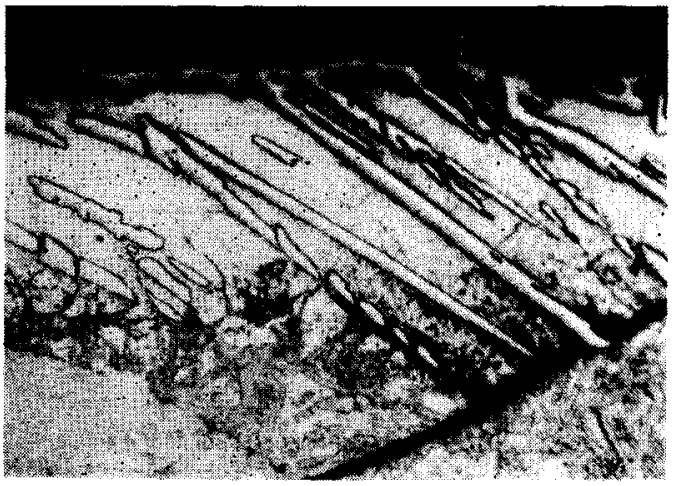

(f) $\mathrm{Ti}-7 \mathrm{Fe}$

Photo.2 Microstructures of $\mathrm{Ti}$ and its alloys at $950^{\circ} \mathrm{C}$ for 6 hours. $(\times 90)$

Table 6 The average thickness of scales formed and $\alpha$-phase of Titanium oxidized at $950^{\circ} \mathrm{C}$.

\begin{tabular}{l|c|c|c}
\hline Time $(\mathrm{hr})$ & 1 & 3 & 6 \\
\hline Scales $(\mathrm{mm})$ & 0.03 & 0.09 & 0.18 \\
$\alpha$-phase $(\mathrm{mm})$ & 0.03 & 0.06 & 0.09 \\
\hline
\end{tabular}

大きく(14)， $\beta$ 相への酸素溶解度が小さいことが 考光られ る、また下地金属周核に带状 $\alpha$ 相を生じた場合はこれをと おしての酸素桩散速度が，木た柱状 $\alpha$ 相のみを生じる場合

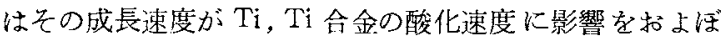
寸すのと思われる。

Fig.4(a) (d) は $1000^{\circ} \mathrm{C}, 6 \mathrm{hr}$ の試料についての X線マイ クロアナライザの line analysis の結果である。図中 scale

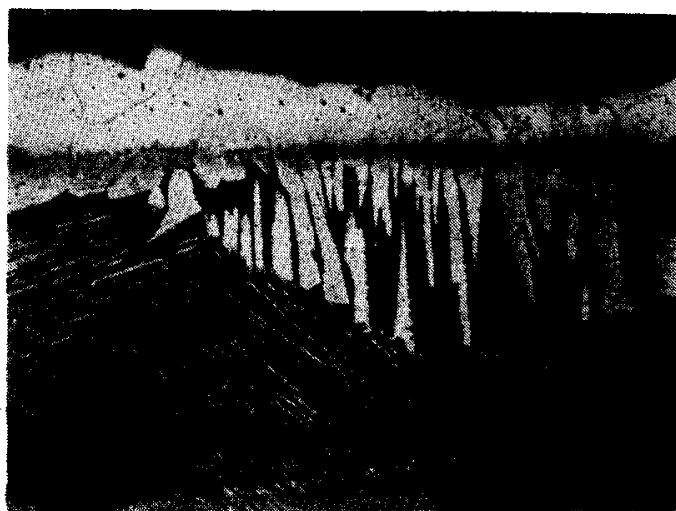

Photo.3 Microstructure of Ti-3 Al alloy oxidized at $1000^{\circ} \mathrm{C}$ for 6 hours. $(\times 90)$ 
$\left(1000^{\circ} \mathrm{C}\right.$ で約 $\left.0.15 \%\right), \beta-\mathrm{Ti}$ は酸素の溶解度が小さい $(1000$ ${ }^{\circ} \mathrm{C}$ で約 $0.45 \%$ ). Fig.4(b)の Fe-K $\alpha$ の強度比から計算す
\& void とあるのは内側酸化被膜の部分であるが, 武料研 摩中に一部が欠けたり, 試料泠却中に外側酸化被膜との間
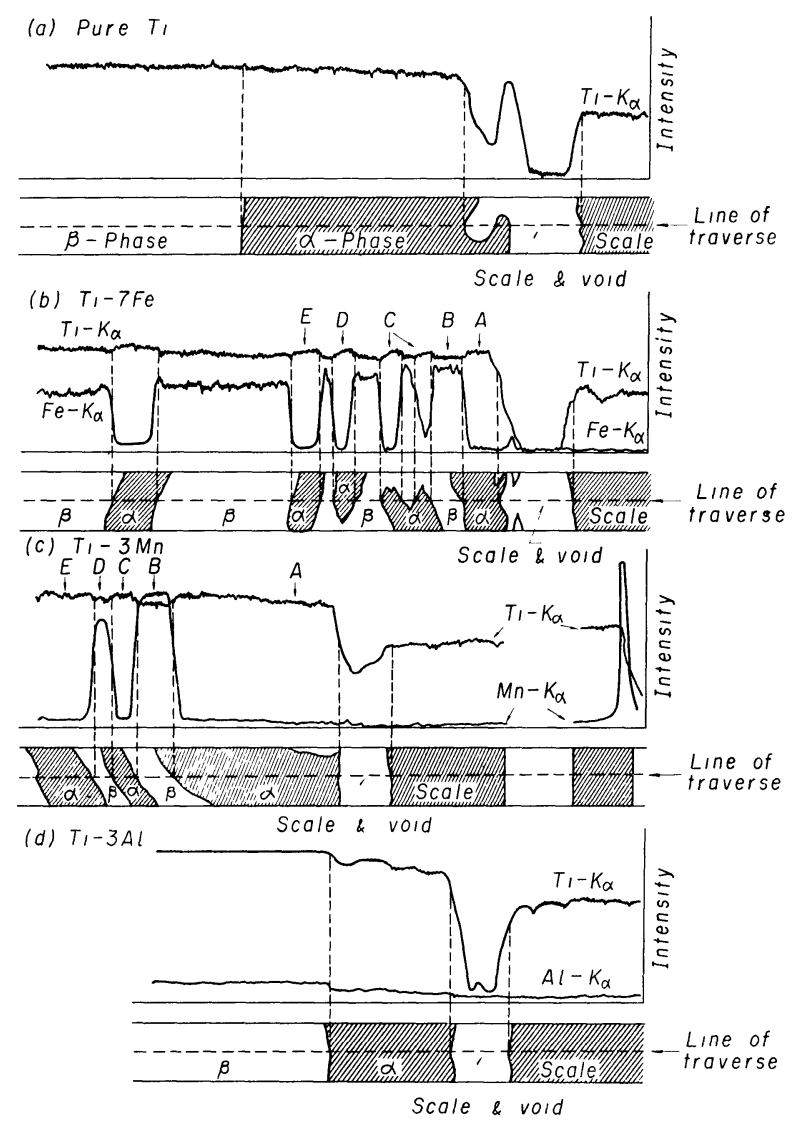

(d) $T_{1}-3 \mathrm{Al}$

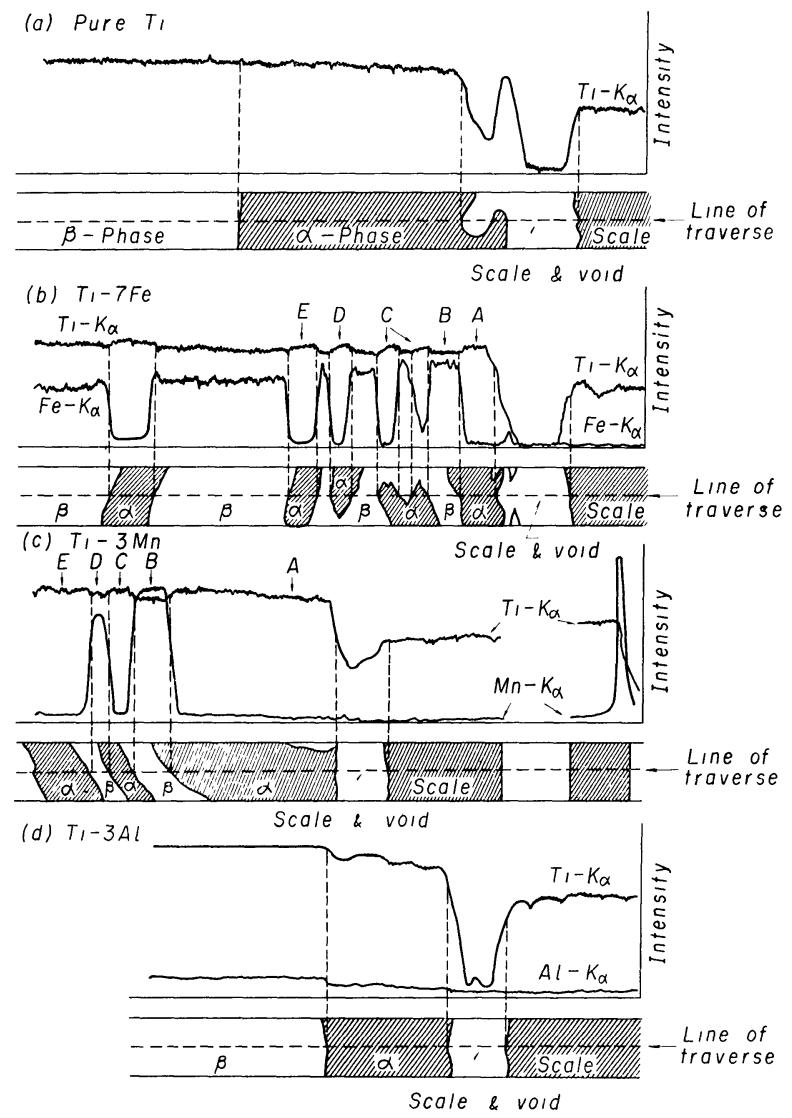

Fig. 4 Line analysis for $\mathrm{Ti}$ and alloying elements in pure $\mathrm{Ti}$ and its alloys oxidized at 1000 ${ }^{\circ} \mathrm{C}$ for 6 hours.

に吵間が生じた部分である。

Fig. 4(a) は純 Ti の結果である. $\alpha$ 相では Ti の濃度分布 に勾配がみられるが， $\beta$ 相(処理温度で $\beta$ 相であつた部分， 以後 $\beta$ 相とよぶ)ではほぼ一様で勾配はほとんど認められ ない、X線マイクロアナライザでは酸素の濃度分布は直接 測定できずTi の濃度分布から推定するより別に方法がな く, 非常に精度が悪い， $\alpha$ 相では酸素濃度勾配が一応認め られるが， $\beta$ 相ではほとんど認められない．Ti酸素が固

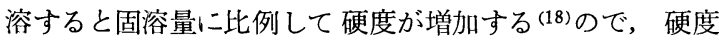
分布から酸素の濃度分布を調べる方が精度が高い，微小硬 度計による硬度測定結果では， $\alpha$ 相では金属表面に接近し て硬度はかなり大きく，内部に入るにつれて急に減少して いるが， $\beta$ 相ではほとんど一定であり，X線マイクロアナ ライザの場合と同じ結論が得られた.

Fig.4 (b) は Ti-7 Fe 合金の結果である。 $\alpha$ 相は Fe 含有量 が少ないが，これと接する $\beta$ 相は Fe 含有量が多い，Ti 含 有量は逆に $\beta$ 相では $\alpha$ 相より幾分少ない，Allen ら(20)の $\mathrm{Ti}-\mathrm{Fe}-\mathrm{O}$ 状態図によると， $\alpha-\mathrm{Ti}$ は $\mathrm{Fe}$ をあすり固溶せず

(20) N.P.Allen et al: J.Inst. Metals, 82 (1953 54),534.

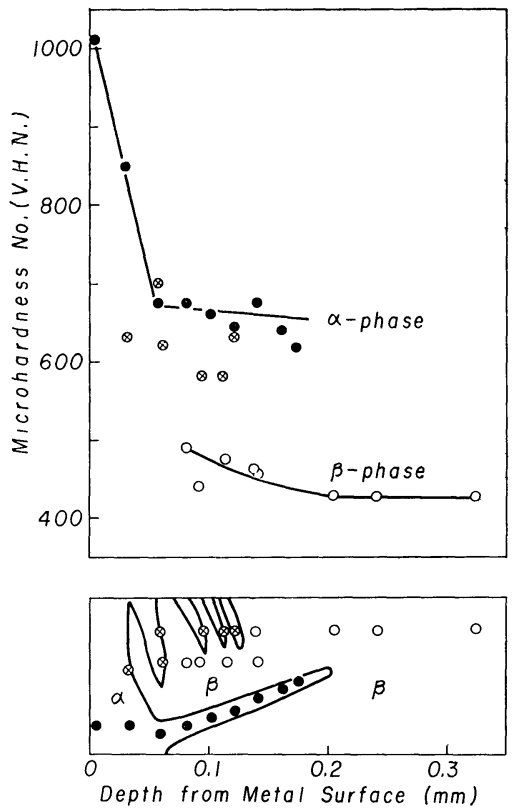

Fig. 5 Microhardness of Ti-3 Fe alloy oxidized for 6 hours at $950^{\circ} \mathrm{C}$ in air.

ると $\mathrm{A}, \mathrm{C}, \mathrm{D}, \mathrm{E}$ などの $\alpha$ 相では $\mathrm{Fe}$ 約 $0.3 \%$ ， $\beta$ 相ではこれより高く，たとえば B で約 $11.8 \%$ と なる。 $\alpha$ 相での Fe 含有量は Allen らの結果 と多少 異なるが，これは強度比のみから計算したためで正 確な们を得るためには適切な補正が必要であるが， この点について汢今後検討したい。带状 $\alpha$ 相 (Fig. 4(b), A の部分)では Ti の濃度勾配が著しい。したがつて酸素濃度 公配著しいと考兄られる。しかし柱状 $\alpha$ 相 (C，D，E)で は酸素濃度勾配はあまり認められず, 硬度測定の結果もこ れと一致している(13) $($ Fig.5)†。この合金では酸化により 生成する $\alpha$ 相の $\mathrm{Fe}$ 固溶度が小さいため $\mathrm{Fe}$ は溶解度の大 きい $\beta$ 相に移るものと考えられる。

Fig.4(c) は Ti-3 Mn 合金の結果で， $\alpha$ 相は Ti-7 Fe 合金 の場合と同様に Mn 含有量が少なく， $\alpha$ 相に接した $\beta$ 相で は Mn 含有量が増加している。一方 Ti 含有量は $\beta$ 相では $\alpha$ 相より幾分少なく $\mathrm{Mn}$ 濃度分布と対応している。 Ti-Mn -O 状態㘠についてはまだ明らかではないが，Ti-Fe-O 状 態図と同様に $\alpha$-Ti の溶解度が小さいと考えられる. $\mathrm{Mn}-\mathrm{K} \alpha$ の強度比から Mn 含有量を計算すると $\alpha$ 相 (Fig. 4 (c) の A， C , E) では $1.08 \%$ 固溶することになる。 $\beta$ 相ではたとえば B では約 13\%，Dでは約 10\%となつている.

Fig.4(d) は Ti-3 Al 合金の結果で, $\alpha$ 相は $\beta$ 相より $\mathrm{Al}$ 含

† Fig. 5 に怙いて®が・に比べて硬度が低いのは, 測定個所の $\alpha$ 相が比較的薄いためと思われる. また $\beta$ 相の硬度が $\alpha$ 相に近いほど 高いのは Fe 含有量が 多いためと考えられる。 
有量がやや少ないが， $\mathrm{Fe}, \mathrm{Mn}$ 合金のような著しい差は認 められなからた。また $\alpha$ 相にはTi 濃度勾配が認められる が, $\beta$ 相では極めて小さいようである. Schofield(21)による と $\alpha$-TiのAl，Oに対する溶解度はかなり大きい，したが つて酸素が固溶して $\alpha$ 相を生じてわA1含有量には差異を 生じないものと考えられる。また Ti 濃度分布から推定し $て \alpha$ 相には酸素濃度勾配が認められるが， $\beta$ 相では少ない ようである，硬度分布測定の結果からあ同様のことが推論 できる。

\section{IV. 喓 括}

(1) 純 $\mathrm{Ti}$ 扣よび $\mathrm{Ti}$ 合金を空気中 $900^{\circ} \sim 1000^{\circ} \mathrm{C}$ て酸化 し増量を連続的心測定した。

(2) X線回折によると生じた酸化被膜は注とんどルチル であるが， $\mathrm{Ti}-7 \mathrm{Mn}$ 合金ではルチルのはかに $\mathrm{MnTiO}_{3}$ と思 われるすのが諗められた。外側の酸化被膜を㔀離した試料

(21) T.H.Schofield and A.E.Bacon: J.Inst. Metals, 85 (1956 57) ,193.
表面についてはASTM の $\mathrm{Ti}_{2} \mathrm{O}$ の回折図形が認められた が，これは酸素を飽和した $\alpha$-Tiである。

（3）下地金属は周縁に酸素を固溶した $\alpha$ 相を生じるが， その成長は温度により異なり，純 Ti を除いていずれる変 態点以上では異状成長をする，带状 $\alpha$ 相では表面と内部の 硬度差はかなり大きいが，柱状 $\alpha$ 相でははとんど一定であ $\eta$ ，带状 $\alpha$ 相での酸素濃度勾配は大をいが，杜状 $\alpha$ 相では 小さいことが判明した。

(4) X線マイクロアナライナ゙により組成元素の濃度分布 を謂べた結果，Ti-Mn，Ti-Fe 合金では酸化により生成す る $\alpha$ 相は $\mathrm{Mn}, \mathrm{Fe}$ の固溶量が小さいため $\mathrm{Mn}, \mathrm{Fe}$ は溶解度 の大きい $\beta$ 相に移ることが楒められたが，Ti-3 Al 合金で は酸化に伴なう $\mathrm{A} 1$ 含有量の変化はあまり忍められなかつ た.

終りに御指導をいただいた東京工大長㱦久弥教授に厚く 御礼申し上げます。また試料の調製は日本釷業 $\mathrm{K} \mathrm{K}$ 有泉 仁勇氏, 東光電気 $\mathrm{K} \mathrm{K}$ 矢島林二郎氏， X線マイクロアナラ イザは日本電子 $\mathrm{KK}$. 島津製作所・日立製作所の力ふ， $\mathrm{X}$ 線回折は山梨大学国富 稔教授・功刀利夫氏の御棜話にな りました，厚く感謝いたします。。 